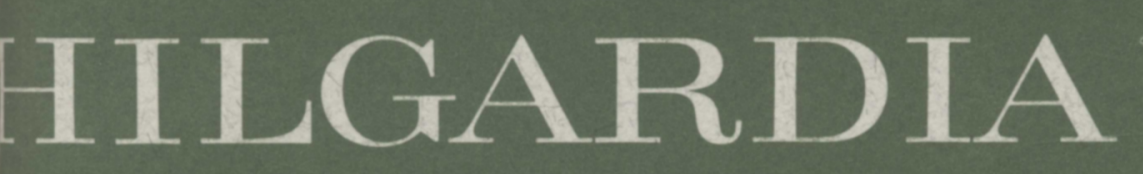

JOURNAL OF AGRICULTURAL SCIENCE PUBLISHED BY HE CALIFORNIA AGRICULTURAL EXPERIMENT STATION

Volume 41, Number 21 - May, 1973

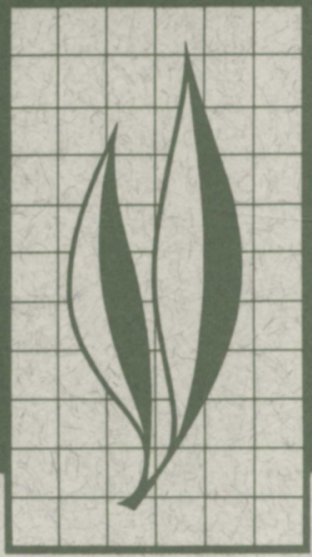

\title{
Chemical Seed Treatment for the Control of Seedling Disease of Water-sown Rice
}

R. K. Webster, D. H. Hall, J. Bolstad, C. M. Wick, D. M. Brandon, R. Baskett, J. M. Williams

This ends Volume 41 


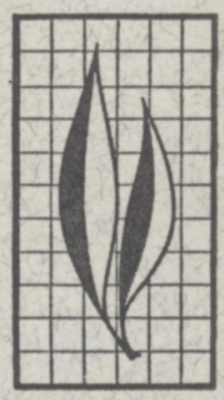

The most effective fungicide formulations, rates, and method of application for reducing seed rot and seedling disease of watersown rice were determined in greenhouse and field studies. The efficacy of over 30 chemical formulations that had shown biological activity against Acblya klebsiana and Pytbium sp. in laboratory and greenhouse trials were tested. Difolatan ${ }^{\otimes}$ and captan treatments have consistently been the most effective in improving total stand establishment. Treatment by either slurry or spray mist with flowable formulations and allowing the fungicide to dry on the seed prior to the soaking process proved to be more effective in preventing seed rot and seedling disease than application made after soaking or by adding the chemicals to the soak water. Seed treated prior to soaking showed no detrimental effects from the chemicals after storage up to four months. Analysis of chemically treated seed before and after soaking and of the soak water revealed that substantial portions of the fungicide were lost during the soaking process. The benefits from fungicide seed treatment in water-sown rice are most obvious during the early planting season, when environmental conditions are often unfavorable for germination and seedling growth.

\section{THE AUTHORS:}

R. K. Webster is Associate Professor of Plant Pathology and Associate Plant Pathologist in the Experiment Station; D. H. Hall is Extension Plant Pathologist; and J. Bolstad is Staff Research Associate-all at Davis, California. C. M. Wick is Farm Advisor, Butte County; D. M. Brandon is Farm Advisor, Colusa, Glenn, and Yolo counties; R. Baskett is Farm Advisor, San Joaquin County; and J. M. Williams is Farm Advisor, Sutter-Sacramento counties. 


\section{Chemical Seed Treatment for the Control of Seedling Disease of Water-sown Rice ${ }^{1}$}

\section{INTRODUCTION}

Rice SEEDling Diseases caused by $A c h$ lya klebsiana Pieters and Pythium species play an important role in the establishment of uniform and optimum stands of water-sown rice in California (Webster et al., 1970a). These diseases, although prevalent throughout the riceproducing areas of California, are generally more severe when temperatures during the planting season are cool and unfavorable for the growth and establishment of seedlings. In the past, growers have compensated for seedling loss by increasing seeding rates, and in severe cases many fields had to be partially or totally replanted. When replanting is necessary, stands obtained are usually less than optimum, and problems in uniform maturation within the limits of the California environment are frequently encountered.

To obtain maximum production from the varieties currently used in California, it is important that fields be sown as soon after April 1 as possible, with the period between April 15 to May 10 considered the optimum. Unfortunately, it is during this time that conditions more favorable for rice seedling disease frequently occur.

The need for an effective, cconomically feasible rice seed treatment has been recognized for some time in California (Finfrock, 1957) and in rice-producing areas in the southern United States (Lamey, 1965; and Cralley and Tullis, 1937). Recent studies (Webster et al., $1970 b$ ) have shown that the practice of soaking the seed prior to sowing into flooded paddies introduces complications not experienced with seed treatment in other cereals. They also demonstrated that fungicide treatments are beneficial in assuring growers adequate uniform stands, provide a substantial savings through the use of lower seeding rates, and virtually eliminate the need to replant.

This report is based on results obtained over the past five years from studies to determine the most effective chemicals, formulation, rate, time, and manner of application and effect of seed treatment on germination of rice seed. The effectiveness of rice seed treatment in relation to planting date has received prime consideration. Since previous practice has been to soak seed in a 1 per cent sodium hypochlorite ( $\mathrm{NaOCl}$ ) solution (Mikkelsen and Sinah, 1961) prior to planting, its continued use was also evaluated.

\section{MATERIALS AND METHODS}

Preliminary screening on efficacy of candidate fungicides was carried out in greenhouse and laboratory trials. Laboratory tests consisted of incorporating the fungicides into standard potato dextrose agar and inoculating the fungicide-containing-media with both zoospores and mycelium of organisms

\footnotetext{
${ }^{1}$ Submitted for publication October 2, 1972.
} 
known to cause rice seedling disease. All fungicides showing some biological activity against the pathogens were included in subsequent trials in both the greenhouse and field.

Screening trials conducted in the greenhouse were done in unperforated seedling pots ( 8 inches in diameter and 4 inches deep). One to 2 inches of pasteurized soil was added to each pot which was then filled with distilled water. Zoospore suspensions of Achlya klebsiana and mycelial fragments of the Pythium sp. were added at the same time that seed treated with the candidate chemicals was placed on the surface of the submerged soil. Per cent emergence through the water of plants from the seeds sown was used in determining effectiveness of the candidate fungicides. Similar screening was carried out with unpasteurized soil obtained from fields with known histories of seedling disease.

Foundation seed, obtained from the California Cooperative Rice Research Foundation, Biggs, California, was used throughout the studies. New seed was obtained each year. Evaluation was made on Calrose, Colusa, and Caloro varieties.

For treatment, 1-pound lots of seed were placed in a 1-gallon capacity aluminum drum with fluted sides. The drum was attached at about 20 degrees from the horizontal to a constant speed motor that turned at about $60 \mathrm{rpm}$. An appropriate amount of each chemical was suspended in 18 to $20 \mathrm{ml}$ of water and applied to the seed by spraying with a DeVilbiss atomizer. The seed was allowed to tumble for about one minute after the fungicides were applied and allowed to dry on a laboratory bench.
All trials reported in the tables were conducted in growers' fields under normal rice culture conditions usually with histories of difficulty in stand establishment. Different planting dates were used where possible for each trial. Galvanized screen, 8 mesh per inch was used in constructing 3 -feet diameter rings, 1 foot deep for each plot. The rings were placed in fields after seedbed preparation but prior to flooding and covered with polyethylene sheeting to exclude non-experimental seed. After the field had been flooded and sown, the polyethylene covers were removed, and known numbers of seed treated with the candidate chemicals were hand sown into the test rings. When the field sites were ready, the test seed was covered with water and allowed to soak for 24 hours followed by draining for 12 to 24 hours to simulate actual field conditions. Per cent stand established was determined by removing and counting all plants that had emerged through the water in the rings 25 to 30 days after planting.

Viability determinations and effect of seed treatment on root and shoot development was carried out in the laboratory in germination chambers. Observations on plant development were also made in a portion of the field trials; walkways were constructed around the rings so that the plants could be observed without walking in the field and muddying the water.

Residue analysis was carried out by standard methods developed and performed in the Department of Environmental Toxicology, University of California, Davis. Statistical evaluation was based on Duncan's Multiple Range test.

\section{RESULTS AND OBSERVATIONS}

Chemicals selected from "poisoned agar" and greenhouse trials for further evaluation in field trials are listed in the text table. Frequently, more than one formulation was tested as indicated under the listing of trade names. 


\begin{tabular}{|c|c|c|}
\hline COMMON NAME & CHEMICAL NAME & $\begin{array}{l}\text { REGISTERED } \\
\text { TRADE NAMES }\end{array}$ \\
\hline thiram & tetramethỵlthiuram disulfide & $\begin{array}{l}\text { Arasan } 50, \text { Arasan } 42 \mathrm{~S}, \\
\text { Vancide TM, Ever- } \\
\text { shield T }\end{array}$ \\
\hline maneb & manganous ethylenebisdithiocarbamate & $\begin{array}{l}\text { Dithane M-22, } \\
\text { Manzate D }\end{array}$ \\
\hline mancozeb & $\begin{array}{l}\text { manganous ethylenebisdithiocarbamate } \\
\text { - coordinated with zinc ion }\end{array}$ & $\begin{array}{l}\text { Dithane M- } 45 \text {, } \\
\text { Dithane Z-78 }\end{array}$ \\
\hline captan & $\begin{array}{l}\mathrm{N} \text {-[trichloromethylthio]-4-cyclohexene- } \\
\text { 1,2-dicarboximide }\end{array}$ & $\begin{array}{l}\text { Captan SP, Orthocide } \\
\text { 50, Evershield CM }\end{array}$ \\
\hline folcid & $\begin{array}{l}\text { tetrachloroethylmercapto-cyclohexene- } \\
\text { dicarboximide }\end{array}$ & Difolatan 4F \\
\hline dichlone & ¿,3-dichloro-1,4-naphoquinone & Phygon XL \\
\hline nabam & disodium ethylenebisdithiocarbamate & none \\
\hline bordeaux & copper sulfate + calcium hydroxide $5: 5$ & none \\
\hline mercury & methyl-mercury proprionate & Metasol MP \\
\hline none & $\begin{array}{l}\text { dimethylaminobenzenediazo sodium } \\
\text { sulfonate ( } p \text { [dimethylamino] benzene- } \\
\text { (liazo sodium sulfonate) }\end{array}$ & Dexon \\
\hline none & $\begin{array}{l}\text { pentachloronitrobenzene }+5 \text {-ethoxy-3- } \\
\text { trichloromethyl 1,2,4 thiadiazole }\end{array}$ & $\begin{array}{l}\text { Terraclor Super X, } \\
\text { Terracoat L- } 21\end{array}$ \\
\hline benornyl & $\begin{array}{l}\text { (1-[butylcarbamoyl]-2-benzimidazole } \\
\text { carbamic acid) }\end{array}$ & Benlate \\
\hline copper & copper hydroxide & Kocide 101 \\
\hline thiabendazole & 2-[4'-thiazoyl] benzimidazole & TBZ \\
\hline chlorothalonil & tetrachloroisophthalonitrile & Daconil 2787 \\
\hline dithianon & $\begin{array}{l}\text { 1,4-dithiaanthraquinone-2,3-dicarboni- } \\
\text { trile }\end{array}$ & Delan \\
\hline none & (a copper zinc chromate complex) & Miller 658 \\
\hline TCMTB & 2-[thiocyanomethylthio] benzothiazole & Busan 72 \\
\hline metiram & zine polyethylenethiuram disulfide & Polyram \\
\hline chlorneb & 1,4-dichloro-2,5-dimethoxybenzene & Demosan $65 \mathrm{~W}$ \\
\hline
\end{tabular}

In addition, several experimental materials and combinations of Arasan 42S and Bordeaux, Dexon and Bordeaux and Dexon and Arasan 42S were tested. The rate of applications per hundredweight of seed was consistent with that recommended by the suppliers for all chemicals tested. Throughout the field testing, difolatan, captan, and thiram showed the most promise, and further study was limited to determining their comparative effectiveness and suitable procedures for use.

\section{Application rates compared}

Captan and thiram were registered for use as rice seed treatments prior to the beginning of our studies. Thus, the rate of application as indicated on their respective labels was used as a starting 
point for comparisons between various rates of application and commercially available formulations. Difolatan was tested at similar rates, although not registered for use on rice at that time.

Trials comparing flowable formulations of captan and difolatan and a water suspension formulation of thiram (Arasan 42S) were carried out in 1968 at the Biggs Rice Experiment Station. As seen in table 1, difolatan treatments resulted in the highest per cent increase of emerged plants, and treatment with $2 \mathrm{oz} / \mathrm{cwt}$ active chemical was as effective as treatment with 4 or $6 \mathrm{oz} / \mathrm{cwt}$.

Since differences in effectiveness of the fungicides could be due to differential adherence to the seed during soak-

TABIE 1

TOTAL STAND INCREASE IN TRIALS COMPARING RICE SEED TREATED WITH DIFFERENT RATES OF DIFOLATAN, CAPTAN, AND THIRAM PRE-SOAKED IN WATER AND WATERPLUS-SODIUM HYPOCLORITE

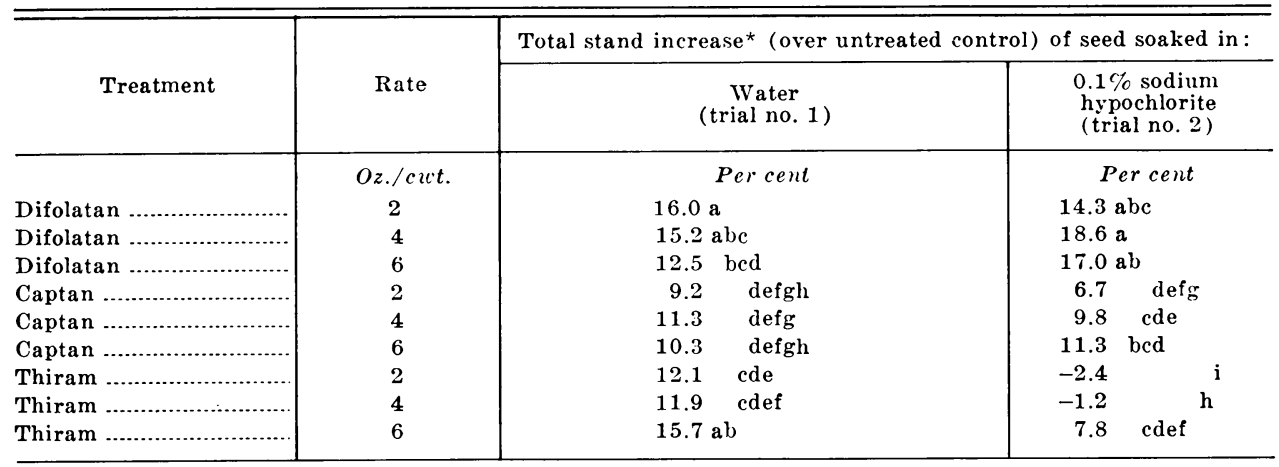

* Each value is the mean of three replications/400 seed/replication. Values with common letters do not differ significantly at the 5 per cent level. Trials were located in the same paddy.

ing and planting, further trials were conducted during the 1969 season. These included comparisons between liquid and wettable powders containing captan and thiram plus the patented adherent Rhoplex ${ }^{\circledR}$ and the commercial formulations (Evershield $\mathrm{CM}^{\circledR}$ and Evershield
$\mathrm{T}^{(\mathbb{1})}$. All treatments in these trials contained 2.4 ounces active ingredient of the fungicide per 100 pounds of rice seed. As seen in tables 2 and 3, captan treatments at $2.4 \mathrm{oz} / \mathrm{cwt}$ were usually more effective than the equivalent thiram treatments. In general, the treat-

TABLE 2

EFFECT OF ADHERENTS ON EFFECTIVENESS OF CAPTAN AND THIRAM AS RICE SEED TREATMENTS

\begin{tabular}{|c|c|c|c|c|}
\hline \multirow{2}{*}{ Treatment* } & \multicolumn{4}{|c|}{ Per cent increase $\dot{\dagger}$ over untreated control in trial no.: } \\
\hline & 1 & 2 & 3 & 4 \\
\hline 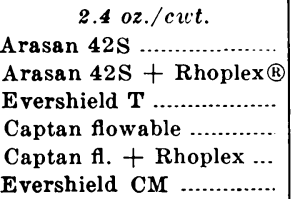 & $\begin{array}{l}-3.9 \text { cd } \\
-1.4 \text { bcd } \\
-2.2 \text { bcd } \\
11.4 \mathrm{a} \\
2.9 \mathrm{~b} \\
8.4 \mathrm{a}\end{array}$ & $\begin{array}{rl}8.3 & \mathrm{~b} \\
4.4 & \mathrm{c} \\
2.1 & \mathrm{c} \\
15.4 \mathrm{a} & \\
9.1 & \mathrm{~b} \\
5.4 & \mathrm{c}\end{array}$ & $\begin{array}{l}23.3 \mathrm{a} \\
11.4 \quad \mathrm{~cd} \\
11.6 \mathrm{~cd} \\
16.1 \mathrm{~b} \\
18.3 \mathrm{ab} \\
12.1 \mathrm{bc}\end{array}$ & $\begin{array}{l}9.4 \mathrm{~b} \\
7.4 \mathrm{bc} \\
8.7 \mathrm{bc} \\
18.3 \mathrm{a} \\
8.7 \mathrm{bc} \\
5.2 \text { bcd }\end{array}$ \\
\hline
\end{tabular}

* $\mathrm{Rhoplex}=$ Rhom Haas adherent used a .5 per cent $\mathrm{v} / \mathrm{v}$ in treatment solution.

$\dagger$ Values represent average of four replications/trial with 200 seed/replication. Values followed by common letters do not differ significantly at the 5 per cent level. 
TABLE 3

EFFECT OF ADHERENTS ON EFFECTIVENESS OF WETTABLE POWDER AND LIQUID FORMULATIONS OF THIRAM AND CAPTAN AS RICE SEED TREATMENTS

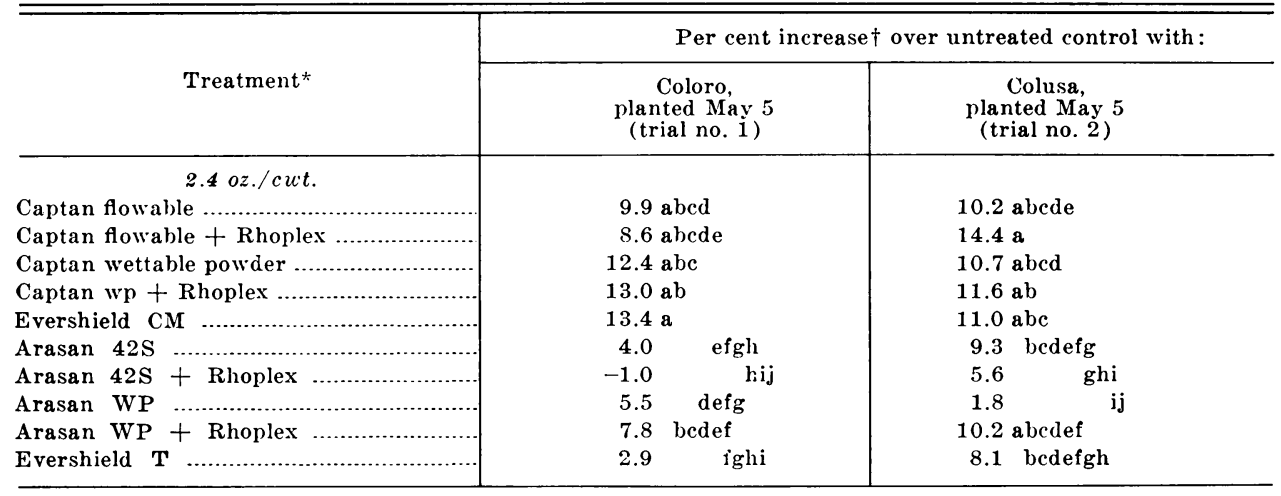

${ }^{*}$ Rhoplex $=$ Rhom Haas adherent used as $.5 \% \mathrm{v} / \mathrm{v}$ in treatment solution. Evershield CM ${ }^{\circledR}$ and Evershield $\mathrm{T}=$ patented formulations of captan and thiram, manufactured by Cargill Inc.

$\dagger$ Values of mean of four replications/trial/200 seed/replication. Common letters indicate no significant difference at the 5 per cent level.

ments including the adherent did not consistently surpass the flowable formulations in effectiveness.

In the next season (1970) additional comparisons between wettable powder, flowable formulations and Evershield formulations of captan and thiram were carried out at three separate test sites. The results are summarized in table 4 . Results from two additional trials comparing the various formulations at three treatment rates with flowable Difolatan

TABLE 4

EFFECTS COMPARED AMONG WETTABLE POWDER, FLOWABLE AND EVERSHIELD FORMULATIONS OF CAPTAN AND THIRAM AS RICE SEED TREATMENTS

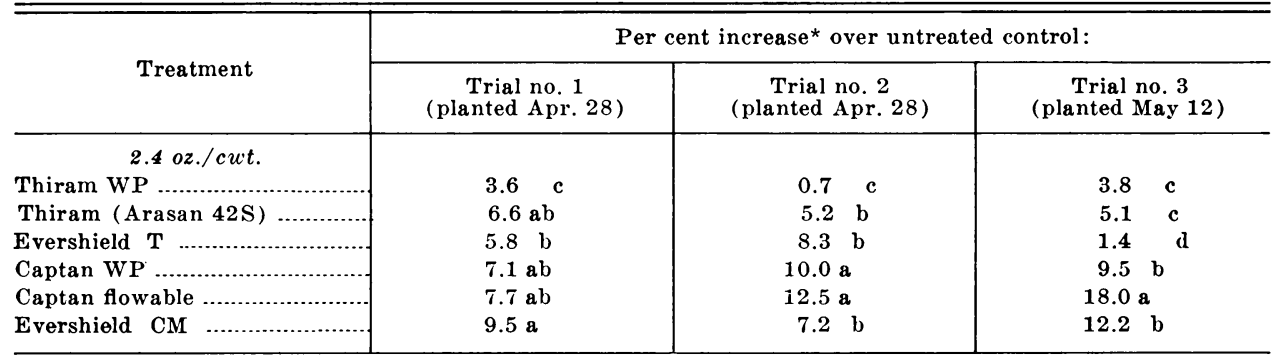

* Average of five replications/200 seed/replication. Common letters indicate no significant difference at the 5 per cent level.

included as a standard are summarized in table 5 ( see also table 6 ).

\section{Residue analysis}

Since treatments at various application rates provided near equal per cent emergence, it was important to determine if the differences or lack of dif- ferences between application rates was due to differential effectiveness of the fungicides or to differential retention of the chemicals on the seed during soaking and planting. To do this, known amounts of seed treated as described under Methods, were soaked for 24 hours and the soak water drained off 
TABLE 5

EFFECTS COMPARED AMONG WETTABLE POWDER, FLOWABLE AND EVERSHIELD FORMULATIONS OF CAPTAN AND THIRAM AT THREE DIFFERENT RATES WITH DIFOLATAN

AS A STANDARD

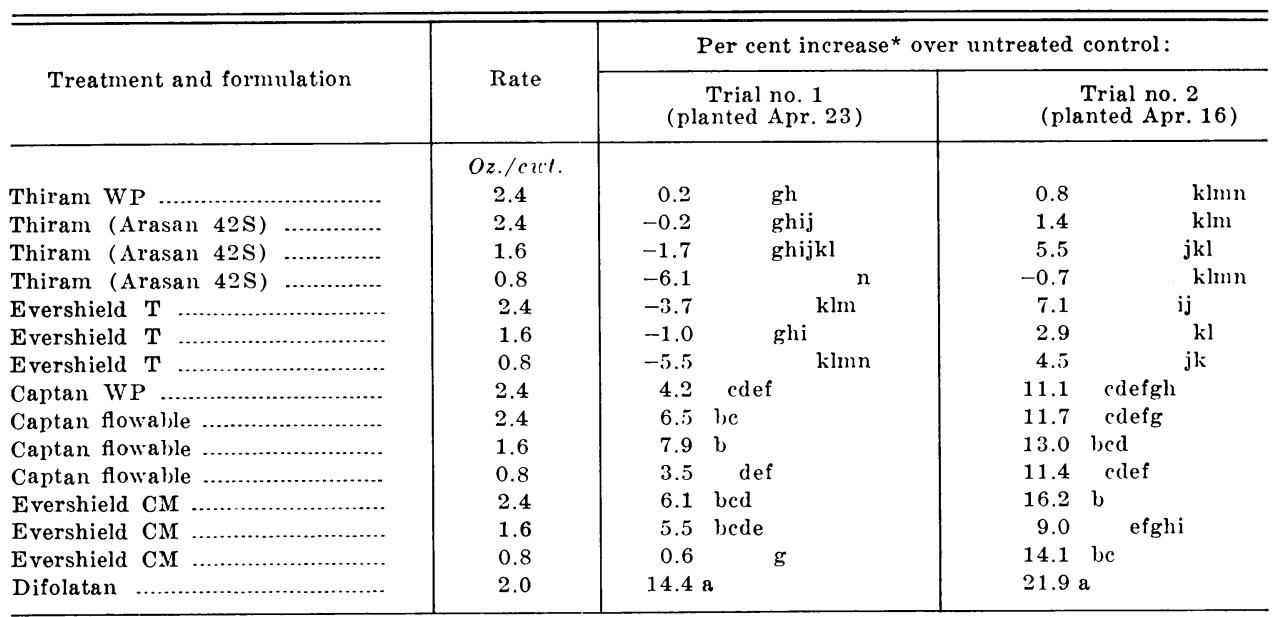

*Values are the mean of five replications with 200 seeds/replication. Common letters indicate no sig. nificant difference at the 5 per cent level.

TABLE 6

CHEMICAL RESIDUE ANALYSIS* SHOWING AMOUNTS OF CHEMICAL REMAINING ON THE SEED AFTER THE SOAKING PROCESS AND CHEMICAL CONCENTRATIONS DETECTED IN THE SOAK IVATER

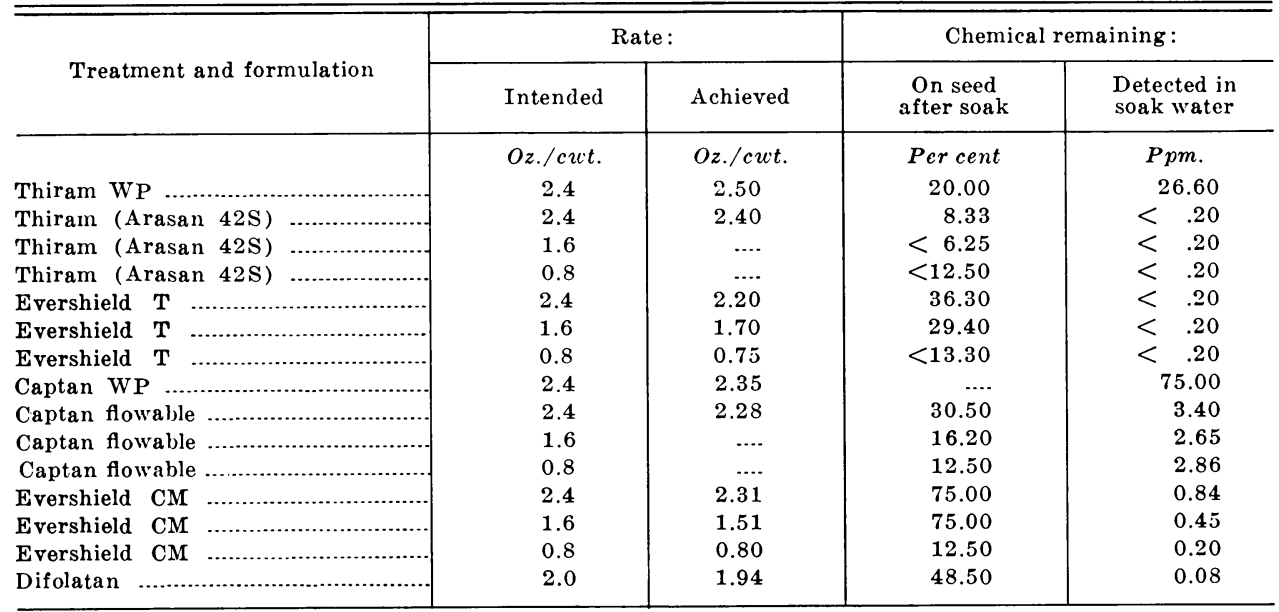

* Data presented here were based on chemical analysis and seed treatment by Cargill Inc. with exception of the results shown for Difolatan.

and frozen until analysis for eluted fungicide was made. The seed was washed with appropriate solvents, and the amount of fungicide remaining after soaking was determined by techniques developed in the U.C. Davis Environmental Toxicology Laboratory for each of the chemicals. The results obtained from representative samples are summarized in table 7 . It is evident that sub- 
stantial portions of the fungicides were lost during the soaking process and that the Evershield formulations resulted in the highest percentage of active ingredient retained through the soaking process. No significant differences in retention of fungicide in treatments including other adherents and the commercial formulations of the fungicides were detected at levels and methods used here.

TABLE 7

AMOUNTS OF ACTIVE CAPTAN, DIFOLATAN, AND THIRAM RETAINED

ON THE SEED SURFACE AFTER SOAKING AND DRAINING*

\begin{tabular}{|c|c|c|}
\hline Fungicide & Rate & $\begin{array}{l}\text { Amount recovered } \\
\text { from seed surface } \\
\text { after soaking } \\
\text { and draining }\end{array}$ \\
\hline & Oz./cutt. & Per cent \\
\hline Captan SP .... & 1 & 55.0 \\
\hline Captan SP .... & 2 & 39.0 \\
\hline Captan SP .... & 3 & 36.6 \\
\hline Arasan $42 \mathrm{~S}$. & 1 & 48.9 \\
\hline Arasan $42 \mathrm{~S}$. & 2 & 42.9 \\
\hline Arasan $42 \mathrm{~S}$ & 3 & 42.0 \\
\hline Difolatan .... & 1 & 52.6 \\
\hline Difolatan $\quad . .$. & 2 & 47.5 \\
\hline Difolatan .... & 3 & 51.6 \\
\hline
\end{tabular}

* Seed treated in 1-lb. lots, allowed to dry, then soaked in plain water for 24 hours and drained prior to residue analysis.

\section{Manner and time of treatment}

Development of seed treatment procedures for water-sown rice is complicated by the standard grower practice of soaking seed rice in bulk tanks (about 1,000 pounds) for 24 hours followed by a 24 -hour draining period before sowing. Thus, the protectant chemical must adhere to the seed in effective concentrations throughout the soaking and planting process to be effective during the initial period of seed germination and seedling establishment. Seed preparation and planting would be greatly facilitated if the protectant chemical could be applied to the seed during the soaking process. Difolatan, captan, and Arasan 42S were tested, therefore, and compared at $4 \mathrm{oz} / \mathrm{cwt}$ with (a) treating before and (b) treating after the soaking process (table 8). Results indicated that application prior to soaking produced the best total stand establishment.

Treated and untreated seed of three varieties were tested at weekly intervals in the laboratory to determine effects on germination of time of treatment. Re-

TABLE 8

EFFECTS COMPARED OF CAPTAN, DIFOLATAN AND THIRAM APPLIED BEFORE AND AFTER THE SOAKING PROCESS AND IN THE SOAK WATER

\begin{tabular}{|c|c|c|c|c|}
\hline Treatment & $\begin{array}{l}\text { Rate of } \\
\text { active } \\
\text { ingredient }\end{array}$ & $\begin{array}{l}\text { Before soak } \\
\text { (trial No. 1) }\end{array}$ & $\begin{array}{c}\text { After soak } \\
(\text { trial No. 2) }\end{array}$ & $\begin{array}{l}\text { Chemical } \\
\text { added to soak } \\
\text { (trial No. } 3 \text { ) }\end{array}$ \\
\hline $\begin{array}{l}\text { Difolatan } \\
\text { Captan } \\
\text { Thiram }\end{array}$ & $\begin{array}{c}\text { oz. } c u t t . \\
4 \\
4 \\
4\end{array}$ & $\begin{array}{r}12.0 \mathrm{a} \\
10.0 \mathrm{a} \\
5.0 \mathrm{~b}\end{array}$ & $\begin{array}{r}2.0 \mathrm{c} \\
-1.0 \mathrm{c} \\
-1.0 \mathrm{c}\end{array}$ & $\begin{array}{r}10.3 \mathrm{a} \\
5.7 \mathrm{~b} \\
6.4 \mathrm{~b}\end{array}$ \\
\hline
\end{tabular}

* Values of per cent increase represent mean value of four replications with 400 seed/replication; values followed by a common letter do not differ significantly at the 5 per cent level.

sults of these comparisons between untreated and treated seed of Coloro, Colusa, and Calrose treated with 2.4 and $4.0 \mathrm{oz} / \mathrm{cwt}$ of captan, arasan $42 \mathrm{~S}$, and Difolatan were similar after 130 days storage. In all cases germination of both treated and untreated seed did not drop below 93 per cent. Thus, it is concluded that seed rice may be treated at convenient times and held in storage -eliminating objectionable delays during the rush of the planting season.

Measurements of the length of the hypocotyl and radicle produced by germinated, treated, and untreated seed were made after seven days. No sig- 
nificant differences were noted when Coloro, Colusa, and Calrose seed treated with $2.4 \mathrm{oz} /$ cwt or $4 \mathrm{oz} / \mathrm{cwt}$ active ingredient of captan, Difolatan, and thiram were compared with their respective untreated controls.

\section{Effects of different planting dates and locations}

Earlier studies (Webster, et al., $1970 a$ ) on the nature of rice seedling disease indicated that severity is substantially influenced by adverse weather conditions, also that the disease is more severe in some fields than others. The efficacy of captan, thiram, and Difolatan in improving stand establishment was tested in various locations and at different planting dates to compare a variety of environmental effects.

Results for the 1970 tests presented in table 9 substantiate conclusions that chemical seed treatment enhances stand establishment and reduces the need to replant. Benefits of seed treatment are most obvious early in the planting season, when more adverse conditions for plant establishment are usually encountered. As the season progresses and weather conditions become more favorable for seed germination and growth, the differences in stand established between treated and untreated seed diminished. There was little change in total survivors where chemical treatment was used, while the numbers of survivors in the untreated checks usually increased as the season progressed.

TABLE 9

COMPARATIVE EFFECTIVENESS OF DIFOLATAN, CAPTAN AND ARASAN 42S AS RICE SEED TREATMENTS AT DIFFERENT PLANTING

DATES AND LOCATIONS

1970

\begin{tabular}{|c|c|c|c|c|c|c|c|c|c|}
\hline \multirow[b]{2}{*}{ Treatment } & \multicolumn{9}{|c|}{ Per cent increase* over untreated control in following county (with planting data): } \\
\hline & $\begin{array}{c}\text { Glenn } \\
\text { Apr. } 14\end{array}$ & $\begin{array}{c}\text { Butte } \\
\text { Apr. } 18\end{array}$ & $\begin{array}{c}\text { Glenn } \\
\text { Apr. } 22\end{array}$ & $\begin{array}{c}\text { Sutter } \\
\text { Apr. } 27\end{array}$ & $\begin{array}{c}\text { Colusa } \\
\text { Apr. } 28\end{array}$ & $\begin{array}{l}\text { Butte } \\
\text { May } 1\end{array}$ & $\begin{array}{r}\text { Butte } \\
\text { May } 4\end{array}$ & $\begin{array}{c}\text { San } \\
\text { Joaquin } \\
\text { May } 5\end{array}$ & $\begin{array}{l}\text { Fresno } \\
\text { May } 9\end{array}$ \\
\hline Difolatan 4 flowable & $23.2 \mathrm{a}$ & $21.6 \mathrm{a}$ & $21.0 \mathrm{a}$ & $18.6 \mathrm{a}$ & $13.3 \mathrm{a}$ & $14.4 \mathrm{a}$ & $7.6 \mathrm{a}$ & $1.8 \mathrm{a}$ & $6.0 \mathrm{~b}$ \\
\hline Captan SP flowable & $19.3 \mathrm{a}$ & $15.3 a$ & $19.6 \mathrm{a}$ & $11.2 \mathrm{~b}$ & $11.3 a$ & $14.0 \mathrm{a}$ & $7.2 \mathrm{a}$ & $3.3 \mathrm{a}$ & $9.5 \mathrm{ab}$ \\
\hline
\end{tabular}

* Mean of six replications/trial with 200 seeds/replication; values with common letters did not differ sig. nificantly at the 5 per cent level.

\section{The sodium hypochlorite soak- with and without fungicides}

In the past, California rice growers have routinely added 1 gallon of a 5.25 per cent solution of $\mathrm{NaOCl}$ per 100 gallons of soak water. This practice is based on the demonstration that rice seed contains a number of organic chemicals that delay germination (Mikkelsen and Sinah, 1961) and that the sodium hypochlorite alters or reduces their concentration allowing faster germination and seedling growth. With the advent of fungicide seed treatments, it was necessary to evaluate the feasibility
TABLE 10

STANDS FROM RICE SEED SOAKED IN $\mathrm{NaOCl}$ SOLUTION COMPARED WITH STANDS FROM SEED SOAKED IN PLAIN WATER

\begin{tabular}{c|c|c}
\hline \hline \multirow{2}{*}{ Trial no. } & \multicolumn{2}{|c}{ Per cent* stand from seed soaked in: } \\
\cline { 2 - 3 } & Water + NaOC1 & Water \\
\hline 1 & 47 & 53 \\
2 & 57 & 59 \\
3 & 50 & 50 \\
4 & 58 & 64 \\
5 & 54 & 60 \\
6 & 59 & 56 \\
7 & 42 & 54 \\
\hline
\end{tabular}

* Mean values, three replications/400 seeds/ replication (trial 1 through 4); mean values, four replications/400 seeds/replication (trials 5 through 7 ). 
of continuing this practice, particularly with fungicide-treated seed. Subsequently, both water-soaked and $\mathrm{NaOCl}$ soaked controls were included in most of the field trials. Comparisons between untreated and fungicide-treated seed soaked with plain water or $\mathrm{NaOCl}$ are summarized in table 1 . The addition of $\mathrm{NaOCl}$ to the soak water was detri- mental when seed was treated with thiram. Table 10 shows comparisons of untreated seed soaked in plain water or $\mathrm{NaOCl}$ solutions of the same concentration normally used by growers. There was no observable benefit from the use of the $\mathrm{NaOCl}$ solution, and in most cases it appeared to reduce total plant stand established under field conditions.

\section{DISCUSSION}

Since available reports on cereal seed treatment deal mainly with total stand established and are usually not related to actual number of seeds originally planted, it is difficult to compare the results reported here with those obtained on other crops. However, the relationship between commonly used seeding rates and per cent stand establishment obtained here with seed treatment merits some comment. For instance, a seeding rate of 150 pounds per acre would result in approximately 50 seeds per square foot, not excluding levies and roadways overlapped by the aircraft during the seeding operation. If one ignores factors other than seedling disease that affect stand establishment in water-sown rice, 70 or more per cent establishment of Difolatan-treated seed would be more than adequate to obtain maximum yields with California varieties and conditions. It is not possible, however, to ignore such factors as wind drift, algae formation, slick seed beds and invertebrate pests. We have demonstrated in large-scale aircraft-sown trials, however, that nearly the same per cent increase in plants per square foot was established with treated seed as was demonstrated in the smaller ring trials. On the other hand, we detected no significant differences in yield per acre between stands of 10,20 or 30 plants per square foot.

Thus, the major benefits in chemical treatment of water-sown rice are due to the following: (1) cost savings from re- duced sceding rates and planting far exceeding the cost of treatment per acre; (2) more uniform stands and subsequent higher yields; and (3) elimination of the occasional needs to replant some fields.

Since the results presented here indicate that both Difolatan and captan treatments result in higher per cent stand established, and higher percentages of chemical are retained on the seed through the soaking process, we anticipate that the use of thiram will be discontinued as a rice seed treatment. A comparison of Difolatan with captan, showed that Difolatan is clearly the most effective. Either Difolatan or captan applied prior to soaking as flowable formulations at rates specified on their respective labels and allowed to dry on the seed, will consistently provide rice growers insurance against poor stands due to seed rot and secdling disease.

Tests on effects of adherents, although limited, indicated that they did not enhance the effectiveness of the flowable formulations. This was generally true of the Evershield $\mathrm{CM}^{\circledR}$ formulation containing captan. However, since Evershield CM treatments appeared to be as effective as flowable captan treatments, the advantage to the grower and the environment may lie in the use of the Evershield formulation. This observation is based mainly on the residue analysis which indicated that lower initial application rates are required to obtain equal amounts of active chemical on the 
seed after the soaking process; thus the amount of fungicide released into set- tling ponds by drainage of soak water at seed processing plants is minimized.

\section{ACKNOWLEDGMENTS}

We thank the following California rice growers for their cooperation: Moore Brothers, Placer Co.; Regnor Paulsen, Art James and Francis DuBois, Sutter Co.; Jacob Bolin and Sons, Sacramento County; Quinton Maxwell, John Hammer and Richard Trimble, San Joaquin County; Herbert Myers, Yolo County; Merton Lausten and the Baker Brothers, Glenn County; Walter Weller, Bruce Wylie and Jimeno Rancho, Inc., Colusa County; and
Charles H. Johnson, Jr., C. C. Mickle, Warren Rose, Newhall Land and Farming Co. (John Gottlund, Supt., $\Lambda$ dams Ranch); Ernest Mattson, Dennis Lindberg, Arthur Lindberg, Sr., and Donald Murphy, Butte Co.

We acknowledge financial support from the California Rice Research Board, the California Cooperative Rice Research Foundation, and Cargill, Inc., Minneapolis, Minnesota, for portions of the study.

\section{LITERATURE CITED}

Cralley, E. M., and E. C. Tullis

1937. Effect of seed treatments on seedling emergence, severity of seedling blight, and yicld of rice. Ark. Agr. Exp. Sta. Bull. No. 345.

Finfrock, Dwight

1957. Seed treatments for rice. Agronomy Dept. Circular. Univ. of California, Davis, California. (Limited distribution).

IAMYYEY, H. A.

1965. A technique for laboratory evaluation of seed treatments to control rice seed rot. Plant Dis. Reporter 49:736-38.

Mikkelsen, D. S., and M. N. Sinah

1961. Germination inhibition of Oryza sativa and control by preplanting soaking treatments. Crop Sci. 1:332-35.

Webster, R. K., D. H. Hall, Jacob Heeres, C. M. Wick, and D. M. Brandon

1970a. Achlya klebsiana and Pythium species as primary causes of seed rot and seedling disease of rice in California. Phytopathology 60:964-68.

Webster, R. K., D. H. HALL, C. M. Wick, and D. M. BRANDON

$1970 b$. Seedling disease and its control in California rice fields. The Rice Journal 73, (8). 

The journal HILGARDIA is published at irregular intervals, in volumes of about 650 to 700 pages. The number of issues per volume varies.

Single copies of any issue may be obtained free, as long as the supply lasts; please request by volume and issue number from:

\section{Agricultural Publications \\ University of California \\ Berkeley, California 94720}

The limit to nonresidents of California is 10 separate titles. The limit to California residents is 20 separate titles.

The journal will be sent regularly to libraries, schools, or institutions in one of the following ways:

1. In exchange for similar published material on research.

2. As a gift to qualified repository libraries only.

3. On a subscription basis- $\$ 7.50$ a year paid in advance. All subscriptions will be started with the first number issued during a calendar year. Subscribers starting during any given year will be sent back numbers to the first of that year and will be billed for the ensuing year the following January. Make checks or money orders payable to The Regents of The University of California; send payment with order to Agricultural Publications at above address. 